\title{
DOUBLE LIP SURGICAL CORRECTION IN ASCHER'S SYNDROME: DIAGNOSIS AND TREATMENT OF A RARE CONDITION
}

doi: 10.1590/S1807-59322008000500022

Pedro Paulo de Andrade Santos, Pollianna Muniz Alves, Valéria Souza Freitas, Lélia Batista de Souza

\section{INTRODUCTION}

Ascher's syndrome is a rare disease first described in 1920 by Ascher, an ophthalmologist from Prague. ${ }^{1}$ The disease is characterized by a double upper lip, blepharochalasis, and nontoxic thyroid enlargement, though the thyroid enlargement may be evident in only $10 \%$ to $50 \%$ of patients. ${ }^{2,3}$ These deformities, though not posing functional problems, may cause severe psychological distress to the affected person because of the disfiguring effect on smiling. ${ }^{4}$ Prompt recognition of this syndrome can prevent unnecessary tests and diagnostic delays, and allow for quicker scheduling of appropriate surgical treatment. ${ }^{5}$

\section{CASE REPORT}

A 56-year-old male came to the clinic complaining of a disfigured upper lip. He reported having this feature since he was 20 years old, and that his son also has the same problem. The patient had no history of trauma. A double upper lip was visible during physical examination (Figure 1) only when the patient smiled. A central constriction dividing the double lip was observed, most likely due to the attachment of the upper frenulum. The patient also presented with bilateral blepharochalasis on his upper eyelids, but there was no clinical indication of thyroid enlargement. A clinical diagnosis of Ascher's Syndrome was made and surgical correction including removal of the "accessory" lip was performed via a transverse elliptical incision under

Oral Pathology Post Graduation Program, Federal University of Rio Grande do Norte (UFRN) - Natal/RN.

Phone: 55843215.4132 / 3215.4138

Email: pedropaulodonto@yahoo.com.br local anesthesia (Figure 2). The incision was subsequently sutured (Figure 3).

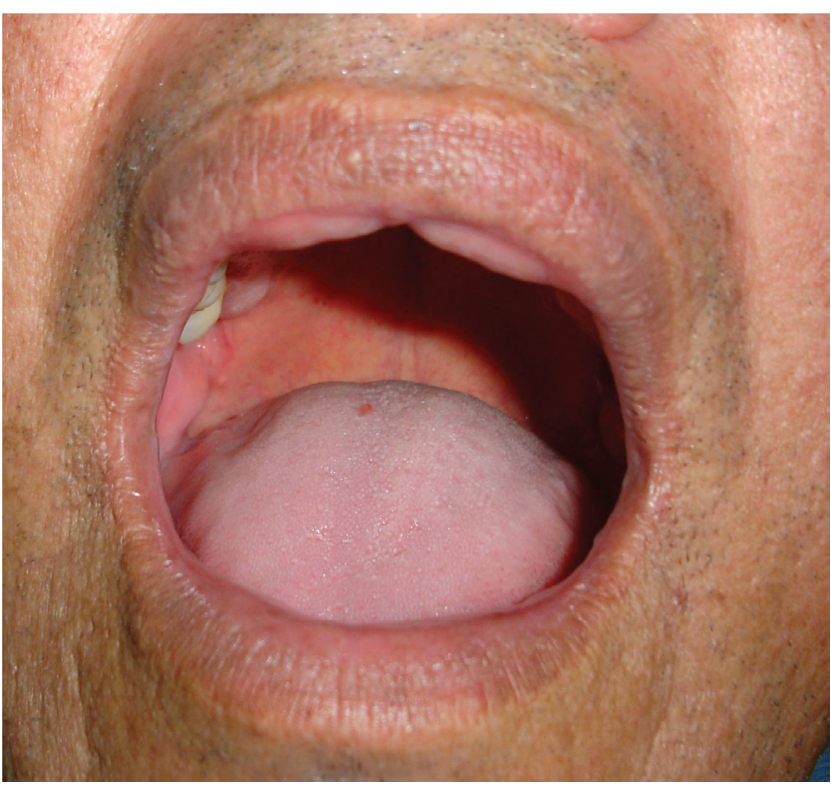

Figure 1 - Double upper lip

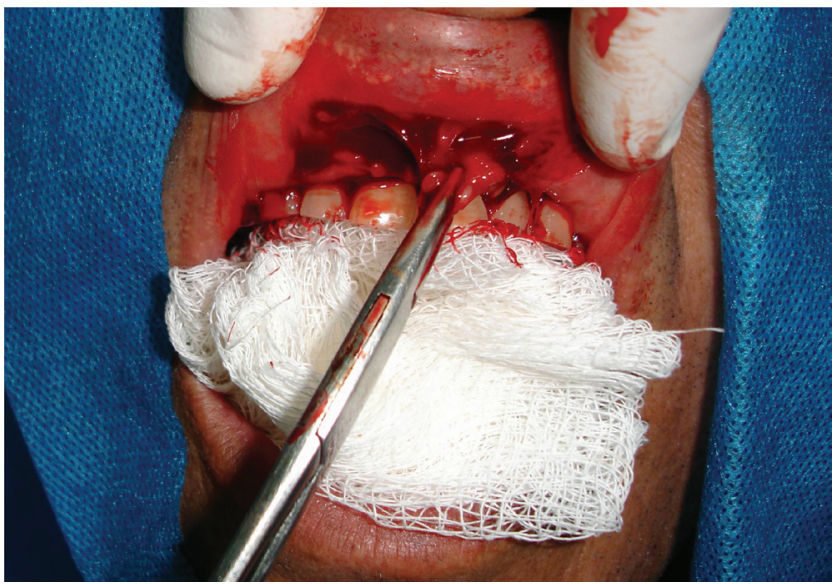

Figure 2 - Surgical correction of "acessory" lip 
The histopathological exam revealed minor salivary gland hyperplasia (Figure 4). No postoperative problems occurred, and the cosmetic results were satisfactory (Figure 5).

\section{DISCUSSION}

Ascher's (or Laffer-Ascher's) syndrome is a combination of blepharochalasis, double lip and non-toxic thyroid enlargement that usually begins in adolescence. Angioneurotic edema on both eyelids as well as on the upper lip constitutes the main early clinical feature of this syndrome. ${ }^{5}$ Other reported conditions associated with double lip include bifid uvula, cleft palate, cheilitis, and facial hemangioma. ${ }^{4}$

Double lip is a rare oral anomaly of congenital or acquired origin that is equally prevalent in both genders and also shows no racial predilection. It usually affects the upper lip bilaterally, ${ }^{6}$ although it can also occur unilaterally in both the upper and lower lips. The condition consists of a fold of excess or redundant hypertrophic tissue on the mucosal side of the lip.?

Upper lip and eyelid edema usually appear at about the same time as each other, and in more than $80 \%$ of cases, Ascher's syndrome manifests itself before the age of $20 .{ }^{5}$ The present report describes a case of Ascher's syndrome with an incidence of double lip and blepharochalasis that presented when the patient was 20 years old.

Acquired cases of the syndrome usually result from trauma, while congenital cases stem from a developmental anomaly. During development, the upper lip mucosa is made up of two transversal zones: an outer cutaneous zone (pars glabra) and an inner mucosal zone (pars villosa). ${ }^{2,4}$ Although the enlargement of the lip may be present from birth, it can become more apparent after the eruption of the teeth. Moreover, it has been suggested that the original double lip may be enhanced by a reactive process after a "sucking-in" of the tissue between the teeth, or maloccluding dentures. ${ }^{8,9}$

Blepharochalasis is a condition characterized by thinning or atrophy, wrinkling and discoloration of the skin of the eyelids, and a subsequent prolapse of orbital fat and lachrymal glands and the ultimate drooping of the affected eyelid. ${ }^{3}$ Other studies have shown that, in cases of blepharochalasis, the skin is not adherent to the underlying tissue; moreover, secondary edema may easily develop. Recurrent edema may aggravate the atrophic changes of the skin overlying the eyelids and cause the elastic skin components to become increasingly flaccid. The excess skin is consistently more prominent laterally than medially. Furthermore, vision is often impaired. ${ }^{3}$

Clinical examination of our patient revealed marked ptosis of the upper eyelids bilaterally, presumably due to

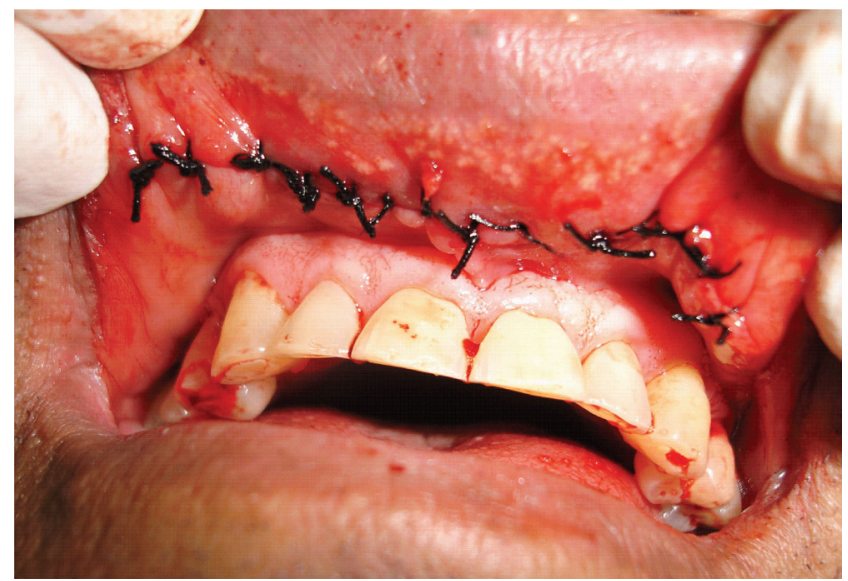

Figure 3 - The "acessory" lip removed and sutured

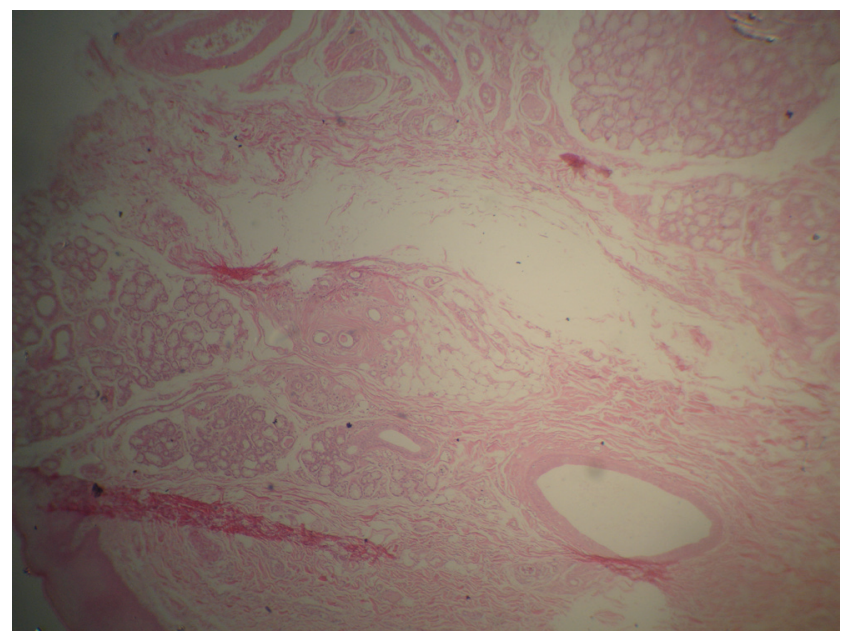

Figure 4 - Minor salivary glands hyperplasia

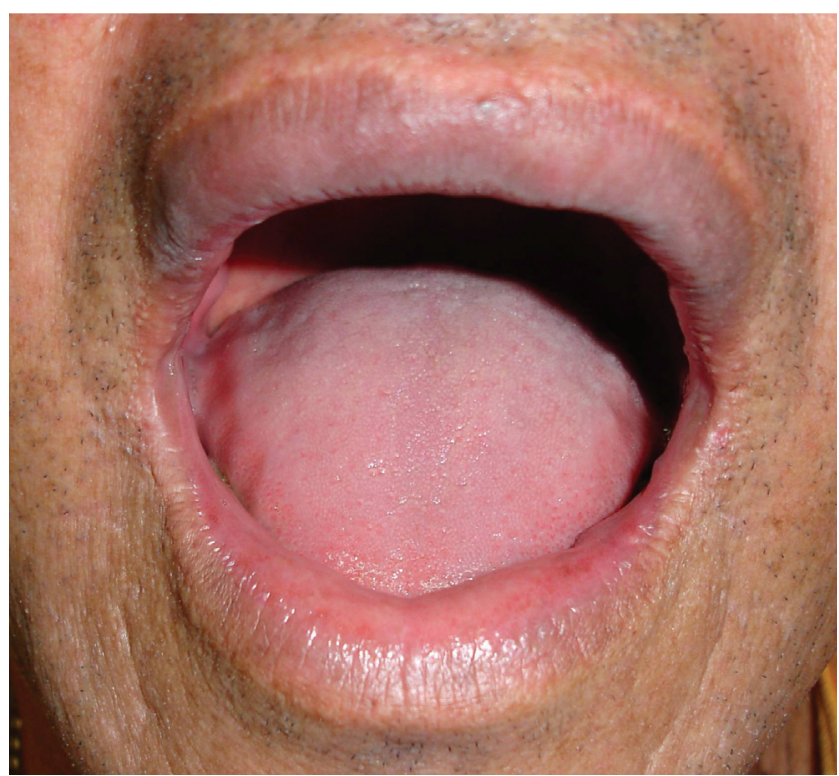

Figure 5 - Cosmetic results satisfactory 
stretching of the levator palpebrae superioris muscle.

Enlargement of the thyroid with variable degrees of severity has often been observed in previous case reports. In Ascher's syndrome, it is present in 10 to $50 \%$ of cases. ${ }^{3,10}$ In our report, the patient presented with normal thyroid function.

Differential diagnosis for Asher's syndrome should also include vascular tumors, lymphangioma, angioedema, cheilitis granulomatosis, Miescher syndrome, salivary gland tumors, inflammatory fibrous hyperplasia, sarcoidosis and plasma cell cheilitis. ${ }^{8,13}$

Reported histological findings include prominent salivary glands and mixed inflammatory cell infiltration. ${ }^{11}$ In our patient, we found prominent salivary glands without inflammatory cell infiltration.

Recurrence of the disease is rarely observed. ${ }^{7,13}$ In the current case, no recurrence was observed over a year of follow up, the patient's prognosis remained good, and no severe systemic problems occurred. ${ }^{3}$

Treatment is indicated when the condition interferes with speech and chewing, or for cosmetic reasons. ${ }^{4}$ Various surgical techniques to correct a double lip have been described, but simple excision through an elliptical incision is usually recommended. ${ }^{6,12,13}$ Some cases start the treatment with Dapsone $50 \mathrm{mg} /$ day to delay progression of the syndrome. ${ }^{10}$ In our case, the double lip was corrected surgically through a transverse elliptical incision.

\section{REFERENCES}

1. Ascher KW. Blepharochalasis mit Struma and Doppellippe. Klin Monatsbl Augenheilkd. 1920;65:85-9.

2. Ali K. Ascher syndrome: a case report and review of the literature. Oral Surg Oral Med Oral Pathol. 2007;103:e26-8.

3. Beinhoff U, Piza-Katzer H. Double lip in a patient with Ascher's syndrome. Eur J Plast Surg. 1998;2:370-3.

4. Suliman MT, Alhassan M. Double lip: Report of five cases and review of the literature. Aesthetic Surg J. 2007;27:289-91.
5. Dalmau J, Puig L, Roé E, Peramiquel L, Pimentel CL, Alomar A. Blepharochalasia and double lip: diagnosis and treatment of Ascher's syndrome. J Eur Acad Dermatol Venereol. 2006;20:1390-1.

6. Reddy KA, Rao AK. Congenital double lip: a review of seven cases. Plast Reconstr Surg. 1989;84:420-3.

7. Chidzonga MM, Mahomva L. Congenital double lower lip: report of a case. Int J Paediatr Dent. 2006;16:448-9. 
8. Costa-Hanemann JÁ, Tostes-Oliveira D, Fernandes-Gomes M, James DA Silvados AM; Sant'Ana E. Congenital double-lip associated to haemangiomas: report of a case. Med Oral. 2004;9:155-8.

9. Alkan A, Metin M. Maxillary double lip: report of two cases. J Oral Sci. 2001;43:69-72.

10. Carraro RRIV, Zanardi D, Pacheco AS, Souza Filho JJ. Você conhece esta síndrome? An Bras Dermatol. 2006;81:287-9.
11. Gomez-Duaso AJ, Seoane J, Garcia JV, Arjona C. Ascher syndrome: report of two cases. J Oral Maxillofac Surg. 1997;55:88-90.

12. Eski M, Nisanci M, Aktas A, Sengezer M. Congenital double lip: review of 5 cases. Br J Oral and Maxillofac Surg. 2007;45:68-70.

13. Martins Wd, Westphalen FH, Sandrin R, Campagnoli E. Congenital Maxillary Double Lip: Review of the literature and Report of a Case. J Can Dent Assoc. 2004;70:466-8. 